\title{
ANALISIS KESALAHAN BERBAHASA PADA TUGAS MATA KULIAH MENYIMAK MAHASISWA PBSI SEMESTER I UNIVERSITAS MUHAMMADIYAH MATARAM TAHUN 2017
}

\author{
Ahyati Kurniamala Niswariyana, Nina \\ Program Studi Bahasa dan Sastra Indonesia Universitas Muhammadiyah Mataram \\ aludragisel@gmail.com
}

\section{INFO ARTIKEL}

\section{Riwayat Artikel:}

Diterima: 25-11-2017

Disetujui: 28-12-2017

\section{Kata Kunci:}

Kesalahan

Berbahasa

Keterampilan

Menyimak

Mahasiswa
ABSTRAK

Abstrak: Bahasa Indonesia mempunyai 2 "slogan keramat" yang selama ini sering kita ucapkan yakni bahasa yang baik dan bahasa yang benar, akan tetapi pada prakteknya ternyata sulit, hal ini tergambar dari bahasa lisan maupun tulisan kita pada umumnya. Tak terkecuali kita sebagai penggiat akademik, baik pengajar maupun peserta ajar tak luput dari kesalahan. Pada penelitian ini, penulis menganalisis kesalahan berbahasa pada tugas mata kuliah menyimak mahasiswa PBSI (Program Bahasa dan Sastra Indonesia) semester I. Penelitian ini bertujuan untuk mengetahui bentuk kesalahan berbahasa pada tugas mahasiswa semester I dalam mata kuliah menyimak, untuk selanjutnya memperbaiki kesalahan tersebut dengan merujuk pada buku pedoman penulisan yang benar. Penelitian ini fokus pada tugas mahasiswa.

Penelitian ini menggunakan kualitatif deskriptif. Dalam penelitian ini, peneliti akan fokus pada kesalahan bahasa tulis sebagai hasil simakan pada tugas mahasiswa semester I. Subjek penelitian adalah mahasiswa PBSI semester I. Data diperoleh melalui metode simak dan metode catat. Analisis data dilakukan dengan reduksi data yang kemudian dilanjutkan dengan penyajian data, dan terakhir verifikasi. Penelitian kualitatif menekankan pada proses, bukan hasil atau produk. Peneliti merupakan instrumen kunci atau pokok dalam penelitian kualitatif.

\section{A. LATAR BELAKANG}

Manusia memiliki empat keterampilan dasar dalam berbahasa yakni keterampilan menyimak, keterampilan berbicara, keterampilan membaca, dan terakhir keterampilan menulis. Keterampilan menyimak tidak dapat dipisahkan dari keterampilan menulis, sebab keduanya saling berkaitan satu sama lain.

Sebagai makhluk sosial manusia yang satu akan berinteraksi dengan manusia lainnya, dalam berbagai lingkungan. Lingkungan akan mengajarkan kita hal baik dan buruk, benar dan salah sehingga kita tumbuh menjadi pribadi yang dewasa dan bijakasana. Lingkungan pertama yang kita kenal adalah keluarga, lingkungan tempat tinggal, kemudian lingkungan sekolah.

Menulis yang baik dan benar terhitung cukup penting bagi kehidupan sosial seseorang terlebih pada profesi pengajar dan pembelajar. Namun menulis kembali hasil simakan menjadi tantangan tersendiri bagi pembelajar dan bagi pengajar sebagai penilai, tentunya.
Pada kenyataannya masih saja terjadi kesalahan berbahasa terutama dalam hal menulis hasil simakan yang dalam hal ini terpokus pada tugas mata kuliah menyimak. Kesalahan berbahasa pada keterampilan menyimak ini tidak hanya dialami oleh sebagian besar mahasiswa, kesalahan semacam ini tak luput juga terjadi pada para pengajar dalam bidangnya masing-masing.

Peneliti dalam hal ini sekaligus bertindak sebagai dosen pada mata kuliah Keterampilan Menyimak pada Program Studi Pendidikan Bahasa dan Sastra Indonesia semester I, menemukan beberapa kesalahan penulisan dari hasil simakan dalam beberapa tugas mahasiswa semester I, seperti terjadinya pelesapan huruf, penghilangan fonem kata, kalimat menjadi tidak padu, letak tanda baca, membedakan di- sebagai kata depan dengan di- sebagai kata kerja, peletakan huruf kapital dan huruf kecil, dan masih banyak lagi. Adanya kesalahan kecil jika tidak diperbaiki akan menimbulkan kesalahan-kesalahan besar. Hal itulah yang mendasari pemikiran peneliti untuk mendata kesalahan yang ada pada tugas Mata Kuliah Menyimak Mahasiswa PBSI untuk selanjutnya diberikan perbaikan. 
Tarigan menyatakan bahwa analisis kesalahan berbahasa dengan menggunakan taksonomi kategori linguistik akan membahas masalah berikut.

1) Kesalahan Fonologi

a. Kesalahan Ucapan

Kesalahan ucapan adalah kesalahan mengucapkan kata sehingga menyimpang dari ucapan baku bahkan menimbulkan perbedaan makna.

b. Kesalahan Ortografi

Kesalahan ortografi (kesalahan ejaan) ialah kesalahan menuliskan kata atau kesalahan menggunakan tanda baca.

2) Kesalahan Morfologi

Kesalahan morfologi adalah kesalahan memakai bahasa disebabkan salah memilih afiks, salah menggunakan kata ulang, salah menyusun kalimat majemuk, dan salah dalam memilih bentuk kata.

3) Kesalahan Sintaksis

Kesalahan sintaksis adalah kesalahan atau penyimpangan struktur frasa, klausa, kalimat, serta ketidaktepatan pemakaian partikel-partikel yaitu menggunakan dua preposisi (dengan dan tanpa) yang mempunyai makna berlawanan.

\section{4) KesalahanLeksikon}

Kesalahan leksikon adalah kesalahan memakai kata yang kurang tepat, sehingga kata tersebut harus diganti dengan kata yang lain. Kata-kata yang dipilih harus tepat mengungkapkan apa yang ingin diungkapkan.

Berdasarkan masalah yang telah dikemukakan di atas tujuan dari penelitian ini adalah:

1) Mengetahui bentuk kesalahan berbahasa pada tugas Mata Kuliah Keterampilan Menyimak Mahasiswa Program Studi Pendidikan Bahasa dan Sastra Indonesia Semester I Universitas Muhammadiyah Mataram tahun 2017, serta mengemukakan perbaikan dari kesalahan berbahasa dalam tugas Keterampilan Menyimak tersebut.

2) Mengetahui faktor penyebab terjadinya kesalahan berbahasa menyimak pada Mahasiswa PBSI semester.

\section{B. METODE PENELITIAN}

\section{Subjek Penelitian}

Adapun yang menjadi subjek pada penelitian ini adalah mahasiswa Program Studi Pendidikan Bahasa dan Sastra Indonesia Universitas Muhammadiyah Mataram tahun 2017 semester I.

\section{Data dan Sumber Data}

Data penelitian merupakan masalah yang dikaji dalam suatu penelitian (Arikunto, 2009:45). Data yang digunakan dalam penelitian ini bersumber dari pengamatan langsung dari tugas menulis mahasiswa, yakni data yang diperoleh dari hasil penganalisisan kesalahan-kesalahan berbahasa pada tugas mahasiswa tersebut. Dalam hal ini yang digunakan sebagai data adalahkalimat-kalimat yang ditulis oleh mahasiswa dalam tugas mata kuliah Keterampilan
Menyimak. Tidak semua tugas menyimak mahasiswa akan digunakan sebagai data kecuali yang dibutuhkan saja.

\section{Teknik Pengumpulan Data}

Teknik pengumpulan data dalam penelitian ini adalah teknik simak, dilakukan dengan cara menyimak penggunaan bahasa pada tugas menyimak mahasiswa semester I. Selanjutnya digunakan teknik catat, adapun teknik catat yang peneliti lakukan adalah dengan cara mencatat data-data yang telah diperoleh lalu dikumpulkan menjadi satu selanjutnya dianalis.

\section{Metode Analisis Data}

Metode analisis data yang digunakan adalah metode analisis deskriptif kualitatif dengan cara melakukan reduksi data terlebih dahulu. Mereduksi data berarti merangkum, memilih hal-hal yang pokok, memfokuskan pada hal-hal yang penting, dicari tema dan polanya, dan membuang yang tidak perlu (Sugiyono, 2010: 338). Setelah mereduksi data, langkah selanjutnya adalah penyajian data. Dalam penelitian kualitatif, penyajian data lebih sering dilakukan dengan teks yang bersifat naratif.

Terkait dengan penelitian yang akan dilakukan, langkah-langkah yang dilakukan oleh peneliti dalam menganalisis data adalah (a) mengumpulkan datadata berupa tugas-tugas mahasiswa semester I, (b) memilah-milah kata atau kalimat yang mengandung unsur kesalahan berbahasa, (c) menginterpretasikan data yang telah didapat sesuai dengan permasalahan yang dianalisis, (d) merumuskan dan menyimpulkan hasil analisis yang telah diperoleh.

\section{HASIL DAN PEMBAHASAN}

Hasil penelitian didapatkan dengan cara menguji hasil simakan mahasiswa semester 1 Program Studi Pendidikan Bahasa Indonesia, tidak semua sampel penulis gunakan. Hasil simakan mahasiswa yang penulis dapatkan, kemudian kami pilih secara random/acak yakni beberapa hasil simakan yang cukup jauh berbeda, hal ini dilakukan untuk mengetauhui sejauh mana kesalahan yang dilakukan mahasiswa. Bahan simakan yang penulis perdengarkan ialah pembacaan berita dari youtube. Sedangkan teori yang digunakan untuk menganalisis hasil simakan mahasiswa ialah teori yang dikemukakan oleh Henry Guntur Tarigan, yang mengklasifikasi kesalahan berbahasa menurut 4 tataran kebahasaan, yakni fonologi, morfologi, sintaksis, dan leksikon.

\section{Berita}

Balada Pak Raden

Saudara, Anda tentu masih ingat dengan boneka si unyil atau dengan Pak Raden. Ya, Suyadi, kreator boneka si unyil kini sedang menggalang dana untuk mengembalikan hak cipta belasan boneka karyanya. Pencipta sekaligus pemeran tokoh Pak Raden itu, ngamen dan menjual sejumlah barang seperti buku hingga lukisan di rumahnya. 
a. Hasil simakan mahasiswa 1.

Saudara Anda masih ingat Boneka si unyil atau Pak raden. Suryadi kreator boneka si unyil kini sedang Menggalang dana untuk Mengembalikan hak cipta belasan boneka karyanya. Suryadi pencipta si unyil sekaligus pemeran tokoh pak raden mengamen dan menjual sejumlah barang seperti menjual buku dan lukisan yg ada di rumahnya.

Analisis kesalahan pada mahasiswa 1

Berdasarkan hasil simakan Mahasiswa 1 di atas, terdapat beberapa kesalahan diantaranya :

$\sim$ Kesalahan Fonologi

Kesalahan fonologi yang dianalisis di sini ialah kesalahan ortografi, kesalahan ortografi (kesalahan ejaan) ialah kesalahan menuliskan kata atau kesalahan menggunakan tanda baca.

Pada kalimat pertama "Saudara Anda masih ingat Boneka si unyil atau Pak raden penggunaan tanda baca koma (,) seharusnya ada diantara kata Saudara dan Anda, sebab "Saudara" di sini digunakan oleh narator sebagai kata sapaan kepada pemirsa. Pada kalimat di atas juga terdapat penggunaan huruf kapital yang bukan pada tempatnya, yakni huruf "B" pada kata "Boneka" yang seharusnya menggunakan "b" kecil. Lalu penggunaan " $\mathrm{r}$ " kecil pada kata "raden" yang merupakan nama orang dan harusnya menggunakan huruf besar sehingga menjadi "Raden".

Pada kalimat kedua, "Suryadi kreator boneka si unyil kini sedang Menggalang dana untuk Mengembalikan hak cipta belasan boneka karyanya. " Harusnya antara "Suryadi" dengan "kreator" di situ terdapat tanda koma (,) sebab merupakan penegasan nama orang yang berprofesi sebagai seorang kreator. Pada kalimat ini juga terdapat penggunaan huruf besar yang bukan pada tempatnya, yakni huruf "M" pada kata "Menggalang" dan "Mengembalikan", karena kedua kata tersebut tidak berada di awal kalimat, jadi seharusnya menggunakan huruf kecil.

Pada kalimat ketiga, "Suryadi pencipta si unyil sekaligus pemeran tokoh pak raden mengamen dan menjual sejumlah barang seperti menjual buku dan lukisan yg ada di rumahnya." Harusnya terdapat tanda koma (,) antara pak Raden dan ngamen, bukan mengamen. Pada kalimat tersebut juga terdapat penggunaan kata yang tidak perlu seperti kata "yg ada" dengan maksud menegaskan keberadaan sesuatu. Kata "menjual" yang seharusnya digunakan sekali saja, tetapi digunakan pada 2 tempat untuk menjelaskan 1 maksud. Kata "mengamen" pada teks asli hanya menggunakan kata "ngamen" saja.

$\sim$ Kesalahan Morfologi
Kesalahan morfologi adalah kesalahan memakai bahasa disebabkan salah memilih afiks, salah menggunakan kata ulang, salah menyusun kalimat majemuk, dan salah dalam memilih bentuk kata.

"Saudara Anda masih ingat Boneka si unyil atau Pak raden". Pada kalimat tersebut terdapat pelesapan kata "tentu" berada di antara kata "Anda" dan "masih", kemudian pelesapan kata "dengan" yang berada kata "masih dan "boneka" serta antara kata "atau" dan "Pak Raden" sehingga menjadi "Saudara, Anda tentu masih ingat dengan boneka si unyil atau dengan Pak Raden".

"Suryadi kreator boneka si unyil kini sedang Menggalang dana untuk Mengembalikan hak cipta belasan boneka karyanya”. Pada kalimat di atas ada pelesapan kata "ya" di awal kalimat. Kalimat seharusnya ialah, "Ya, Suyadi, kreator boneka si unyil kini sedang menggalang dana untuk mengembalikan hak cipta belasan boneka karyanya."

Kalimat "Suryadi pencipta si unyil sekaligus pemeran tokoh pak raden mengamen dan menjual sejumlah barang seperti menjual buku dan lukisan yg ada di rumahnya" terdapat penambahan beberapa kata diantaranya "Suryadi, si unyil, me(ngamen), menjual, dan yg ada", penabahan katakata yang tidak perlu dianggap tidak efektif, sebab merupakan pemubaziran. Kalimat seharusnya ialah"Pencipta sekaligus pemeran tokoh Pak Raden itu, ngamen dan menjual sejumlah barang seperti buku hingga lukisan di rumahnya."

$\sim$ Kesalahan Sintaksis

Kesalahan sintaksis adalah kesalahan atau penyimpangan struktur frasa, klausa, kalimat, serta ketidaktepatan pemakaian partikel-partikel yaitu menggunakan dua preposisi (dengan dan tanpa) yang mempunyai makna berlawanan.

"Saudara Anda masih ingat Boneka si unyil atau Pak raden" kesalahan yang terdapat pada kalimat di atas ialah, kurangnya beberapa kata dan penempatan tanda baca sebagaimana telah dijelaskan pada bagian fonologi dan morfologi sebelumnya, sehingga membuat kalimat tersebut kurang efektif dan cenderung berpotensi sebagai pertanyaan, bukan pernyataan sebagaimana seharusnya.

"Suryadi kreator boneka si unyil kini sedang Menggalang dana untuk Mengembalikan hak cipta belasan boneka karyanya" kesalahan yang terdapat pada kalimat di atas ialah kurangnya kata "Ya" dan tanda baca koma (,) yang mampu menegaskan kalimat tersebut sebagai kalimat berita.

"Suryadi pencipta si unyil sekaligus pemeran tokoh pak raden mengamen dan menjual sejumlah barang seperti menjual buku dan lukisan 
yg ada di rumahnya" kesalahan yang terdapat pada kalimat ini ialah, terjadi penambahan beberapa kata yang tidak perlu sebagaimana telah dijelaskan sebelumnya sehingga membuat kalimat tersebut menjadi tidak efektif.

$\sim$ Kesalahan Leksikon

Kesalahan leksikon adalah kesalahan memakai kata yang kurang tepat, sehingga kata tersebut harus diganti dengan kata yang lain. Kata-kata yang dipilih harus tepat mengungkapkan apa yang ingin diungkapkan.

Kesalahan leksikon yang terdapat dalam hasil simakan mahasiswa 1 di atas, ialah pada kata "mengamen" diganti "ngamen", "yg" diganti "yang".

b. Hasil simakan mahasiswa 2.

Suryadi seorang kreator boneka si unyil yang sering disebut Pak Raden kini sedang menggalang dana untuk mengembalikan Hak Cipta belasan boneka miliknya. Ia mengamen, menjual buku dan menjual lukisan yang ada dirumahnya.

Analisis kesalahan pada mahasiswa 2.

Berdasarkan hasil simakan mahasiswa 2 di atas, terdapat beberapa kesalahan diantaranya :

$\sim$ Kesalahan Fonologi

Kesalahan fonologi yang dianalisis di sini ialah kesalahan ortografi, kesalahan ortografi (kesalahan ejaan) ialah kesalahan menuliskan kata atau kesalahan menggunakan tanda baca.

1) "Suryadi seorang kreator boneka si unyil yang sering disebut Pak Raden kini sedang menggalang dana untuk mengembalikan Hak Cipta belasan boneka miliknya”. Kesalahan yang terdapat pada kalimat tersebut yakni tidak ada tanda koma (,) di belakang kata "Suryadi" sebagai penegasan, penggunaan huruf besar pada kata "Hak" dan "Cipta" harusnya menggunakan huruf kecil sebab kedua kata tersebut berada di tengah kalimat dan bukan pula kata yang diistimewakan.

2) "Ia mengamen, menjual buku dan menjual lukisan yang ada dirumahnya. "Kesalahan fonologi pada kalimat di atas, tidak ada koma di antara kata "buku" dan "dan".

$\sim$ Kesalahan Morfologi

Kesalahan morfologi adalah kesalahan memakai bahasa disebabkan salah memilih afiks, salah menggunakan kata ulang, salah menyusun kalimat majemuk, dan salah dalam memilih bentuk kata.

1) "Suryadi seorang kreator boneka si unyil yang sering disebut Pak Raden kini sedang menggalang dana untuk mengembalikan Hak Cipta belasan boneka miliknya. " Kami mengacu pada kalimat asli dari kutipan berita di atas, kesalahan yang terdapat yakni adanya pelesapan kata "Ya", penambahan kata "seorang", "yang”, "sering”, “disebut", dan "Pak Raden".

2) "Ia mengamen, menjual buku dan menjual lukisan yang ada dirumahnya. " Pada kalimat di atas terdapat penambahan kata "Ia", "me(ngamen)",dan kata "menjual" yang berlebihan. Sedangkan pelesapan kata yang terdapat pada kalimat di atas ialah hilangnya kata "pencipta", "sekaligus" , "pemeran", "tokoh", "Pak", "Raden”, "itu”, "sejumlah", "barang", "seperti", dan "hingga".

$\sim$ Kesalahan Sintaksis

Kesalahan sintaksis adalah kesalahan atau penyimpangan struktur frasa, klausa, kalimat, serta ketidaktepatan pemakaian partikel-partikel yaitu menggunakan dua preposisi (dengan dan tanpa) yang mempunyai makna berlawanan.

1) "Suryadi seorang kreator boneka si unyil yang sering disebut Pak Raden kini sedang menggalang dana untuk mengembalikan Hak Cipta belasan boneka miliknya”. Kesalahan sintaksis yang terdapat pada kalimat di atas ialah tidak menulis kalimat pertama yakni "Saudara, Anda tentu masih ingat dengan boneka si unyil atau dengan pak Raden", penambahan kalimat "yang sering disebut pak Raden".

2) "Ia mengamen, menjual buku dan menjual lukisan yang ada dirumahnya", kalimat tersebut kurang lengkap, terdapat pelesapan pada awal kalimat yakni "Pencipta sekaligus pemeran tokoh Pak Raden itu".

$\sim$ Kesalahan Leksikon

Kesalahan leksikon adalah kesalahan memakai kata yang kurang tepat, sehingga kata tersebut harus diganti dengan kata yang lain. Kata-kata yang dipilih harus tepat mengungkapkan apa yang ingin diungkapkan.

"Suryadi seorang kreator boneka si unyil yang sering disebut Pak Raden kini sedang menggalang dana untuk mengembalikan Hak Cipta belasan boneka miliknya. Ia mengamen, menjual buku dan menjual lukisan yang ada dirumahnya", kesalahan leksikon kata "Ia", "mengamen", "menjual", "yang”, dan "ada".

\section{Faktor penyebab terjadinya kesalahan menyimak.}

Ada 2 faktor yang menyebabkan kesalahan dalam menyimak yaitu :

a. Faktor internal

Faktor internal diantaranya ialah kesalahan pada indra pendengar penyimak, kurangnya konsentrasi si penyimak, penyimak kurang memperhatikan, dan suasana hati penyimak saat itu. 


\section{b. Faktor eksternal}

Adapun faktor eksternal yang mempengaruhi buruknya hasil simakan yakni suasana ruang kelas yang kurang kondusif untuk menyimak, audio kurang keras, posisi tempat duduk, teman-teman yang ribut sehingga membuat konsentrasi buyar, suara-suara dari luar ruang kelas.

\section{KESIMPULAN DAN SARAN}

1. Kesalahan berbahasa dalam menyimak yang terjadi pada mahasiswa meliputi tataran fonologi, morfologi, dan sintaksis, masih banyak dilakukan oleh mahasiswa.

2. Faktor yang mempengaruhi kesalahan berbahasa dalam menyimak mahasiswa program studi Pendidikan Bahasa Indonesia semester 1 ada 2 : yakni Faktor internal diantaranya ialah kesalahan pada indra pendengar penyimak, kurangnya konsentrasi si penyimak, penyimak kurang memperhatikan, dan suasana hati penyimak saat itu.

3. Adapun faktor eksternal yang mempengaruhi buruknya hasil simakan yakni suasana ruang kelas yang kurang kondusif untuk menyimak, audio kurang keras, posisi tempat duduk, teman-teman yang ribut sehingga membuat konsentrasi buyar, suara-suara dari luar ruang kelas.

\section{DAFTAR PUSTAKA}

[1]. --------- Kamus Besar Bahasa Indonesia edisi keempat tahun 2012. Jakarta : PT Gramedia.

[2]. Alwi, Hasan dkk. 2003. Tata Bahasa Baku Bahasa Indonesia. Jakarta : Balai Pustaka.

[3]. Arifin, Zainal. 2004. Cermat Berbahasa Indonesia. Jakarta: Akademi Presindo.

[4]. Bungin, Burhan. 2001. Metodologi Penelitian Sosial (Format-format Kuantitatif dan Kualitatif). Surabaya: Airlangga University Press.

[5]. Ebtanastiti, Dyah Fajar \& Muis Tamsil. 2014. Survey Pilihan Karir Mahasiswa Fakultas Matematika dan Ilmu Pengetahuan Alam Universitas Negeri Surabaya.

[6]. Surabaya: Jurnal Mahasiswa UNESA.

[7]. Farchan, Ahmad Sudaryanto. 2013. Analisis Kesulitan Menyimak Mahasiswa Semester II Prodi Pendidikan Bahasa Jepang. Semarang :Skipsi.

[8]. Nawangsasi, Endah. 2015. Analisis Kesalahan Berbahasa Mahasiswa S1 Manajemen Tahun 2011 STIE AUBSurakarta. Surakarta: Jurnal Ilmiah.

[9]. Sugiyono. 2010. Metode Penelitian Pendidikan: Pendekatan Kuantitatif,Kualitatif, dan R\&D. Bandung: Alfabeta.

[10]. Sukardi. 2004. Metodologi Penelitian Pendidikan (Kompetensi dan Praktiknya). Jakarta: PT Bumi Aksara.

[11]. Tarigan, Henry Guntur. 1986. Keterampilan Menyimak. Jakarta :

[12]. Karunia Wirastuti, Intan. 2013. Analisis Kesalahan Berbahasa pada Penulisan Latar Belakang Skripsi Mahasiswa Non Bahasa dan Sastra Indonesia Universitas Muhammaiyah Surakarta. Surakarta: Skripsi. 